\title{
AMFR Gene
}

National Cancer Institute

\section{Source}

National Cancer Institute. AMFR Gene. NCI Thesaurus. Code C28525.

This gene plays a role in tumor cell motility and is associated with several carcinomas. 